\title{
A brief report on the bioaccumulation of small terrestrial mammals: a suggestion for a new line of research in Brazil
}

\section{Breve relato sobre bioacumulação em pequenos mamíferos terrestres: uma sugestão para nova linha de pesquisa no Brasil}

\author{
Felipe Santana Machado, II, III (1) | Aloysio Souza de Moura III (D) | Ravi Fernandes Mariano III (1) \\ Rosângela Alves Tristão Borém ${ }^{\text {IV }}$ (D) | Marco Aurélio Leite Fontes ${ }^{\text {III }}$ (D) \\ 'Governo do Estado de Minas Gerais. Escola Estadual Professora Ana Letro Staacks. Timóteo, Minas Gerais, Brasil \\ "Prefeitura Municipal de São Gonçalo do Sapucaí. Escola Municipal Bento Gonçalves Filho. São Gonçalo do Sapucaí, Minas Gerais, Brasil \\ I'U Universidade Federal de Lavras. Departamento de Ciências Florestais. Lavras, Minas Gerais, Brasil \\ Iv Universidade Federal de Lavras. Departamento de Biologia. Lavras, Minas Gerais, Brasil
}

\begin{abstract}
Small mammals are potential elements to evaluate mining impacts because they occupy key positions in food webs and can be sampled using relatively inexpensive, easy and quick methods. They have been used as environmental indicators for various purposes, such as ecological succession gradients and pollution, among others. However, little is mentioned about bioaccumulation in South America. Our objective is to present data from a heavy metal accumulation test using the Brazilian gracile opossum Gracilinanus microtarsus (J. A. Wagner, 1842) as an experimental model. We concluded that the contents of heavy metals found in the animals' tissues showed differences when compared to other individuals of the same species from an area without the influence of heavy metals. As a result, we encourage the scientific community to carry out more studies in this little mentioned line in the literature in South America and incipient in Brazil.
\end{abstract}

Keywords: Bioaccumulation of heavy metals. Didelphimorphia. Ecology. Gracilinanus microtarsus.

Resumo: Pequenos mamíferos são elementos potenciais para avaliar os impactos da mineração, porque ocupam posições-chave nas redes alimentares e podem ser amostrados usando métodos relativamente baratos, fáceis e rápidos. Eles têm sido utilizados como indicadores ambientais para diversos fins, como gradientes de sucessão ecológica, poluição, entre outros. No entanto, pouco é mencionado sobre a bioacumulação na América do Sul. Nosso objetivo é apresentar os resultados de um teste realizado com um pequeno marsupial da espécie Gracilinanus microtarsus (J. A. Wagner, 1842), no qual foi concluído que o conteúdo de metais pesados encontrados nos tecidos do animal apresentou diferenças quando comparado a outro indivíduo da mesma espécie proveniente de uma área sem influência de metais pesados. Com esses resultados, procuramos incentivar a comunidade científica a realizar mais pesquisas nessa linha, pouco mencionada na literatura da América do Sul e incipiente para o Brasil.

Palavras-chave: Bioacumulação de metais pesados. Didelphimorphia. Ecologia. Gracilinanus microtarsus.

MACHADO, F. S., A. S. MOURA, R. F. MARIANO, R. A. T. BORÉM \& M. A. L. FONTES, 2020. A brief report on the bioaccumulation of small terrestrial mammals: a suggestion for a new line of research in Brazil. Boletim do Museu Paraense Emílio Goeldi. Ciências Naturais 15(3): 809-816. DOI: http://doi.org/10.46357/bcnaturais.v15i3.217.

Autor para correspondência: Felipe Santana Machado. Universidade Federal de Lavras. Departamento de Ciências Florestais. Campus Universitário. Caixa Postal 3037. CEP 37200-000 (epilefsama@hotmail.com).

Recebido em 30/11/2019

Aprovado em 01/10/2020

Responsabilidade editorial: Alexandra Maria Ramos Bezerra
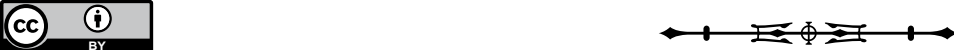


\section{INTRODUCTION}

Brazil has suffered from an increasing impact of mining activities in recent years, such as the collapse of dams in Minas Gerais state, thereby affecting important watersheds of the Southeastern and Northeastern regions of Brazil, such as the Doce River and São Francisco River basins (Cionek et al., 2019; Thompson et al., 2020). In addition to rupturing dams, mining activities can release contaminants through the acidic drainage of wastes, erosion, and surface runoffs (Fan et al., 2014; Vosoogh et al., 2016).

Small mammals are potential elements to evaluate the mining impacts because they occupy key positions in food webs (Kaufman et al., 1998) and can be sampled using relatively inexpensive, easy and quick methods (Graipel et al., 2003; Astúa et al., 2006; Hice \& Velazco, 2013). These animals have been used as environmental indicators (Machado et al., 2013) for a wide range of purposes, such as changes in agriculture (Fischer et al., 2011), ecological succession (Briani et al., 2004), and altitude gradients (Moreira, J. et al., 2009), and seed dispersal (Horn et al., 2008; Andreazzi et al., 2009). Rodents and marsupials are the most diverse terrestrial group of mammals in numbers of species and sub-species (Costa et al., 2005; Paglia et al., 2012). Small mammals act in a fundamental way in the trophic chain, contributing to the control and dispersion of plant species, serving as prey for larger predators, and controlling smaller species (invertebrates, other mammals, reptiles and birds) (Redford \& Eisenberg, 1992).

We can also take measurements aiming to understand bioaccumulation processes from these mammals, since most species of these groups are omnivores and habitat generalists, therefore they are able to acquire different doses of chemical elements (metals or not) from various food sources (Hunter et al., 1989). Heavy metals can enter food chains by plants and soil fauna, and in heavy metal accumulation areas, small mammals can present a high concentration of heavy metals in their kidney and bone tissues, and is usually correlated with its diet
(Ma, 1989), mainly composed small invertebrates (Santori et al., 1997, 2012; Finotti et al., 2012). Many herbivores are less affected than carnivores/omnivores as the heavy metals are absorbed in derisory amounts by them (Ma et al., 1983). However, earthworms and other soil invertebrates present high accumulation potential when they reside in heavy metal accumulation sites (Ma et al., 1983).

The mining impacts in Brazil are disastrous and the contamination means in environments must be evaluated, including bioaccumulation in animals. Thus, herein we present data from a heavy metal accumulation test using the Brazilian gracile opossum Gracilinanus microtarsus (J. A. Wagner, 1842) as an experimental model. As a result, we encourage the scientific community to perform more studies on little mentioned line of research in the literature and incipient in Brazil.

\section{MATERIAL AND METHODS}

We performed an experimental test with two individuals of the Gracilinanus microtarsus species to analyze the bioaccumulation of heavy metals, one collected in a mining pit and the other in a natural environment. The first one (CMUFLA 2474) was captured in a mining area with high cadmium ( $\mathrm{Cd}$ ) and lead $(\mathrm{Pb})$ contents, located in Vazante municipality (17 55' 23" S, 46 48' 56" W-650 m), Minas Gerais state, Brazil (Figure 1).

In order to verify if the marsupial collected in the mining area had higher concentrations of cadmium and lead than other marsupials of the same species which were not exposed to these heavy metals, quantitative analyzes of cadmium and lead were carried out from tissues of both the animal test and from other individuals (frozen) from the Federal University of Lavras (UFLA) Mammalian Collection (CMUFLA), herein referred to as control samples. The animal control was collected in Itutinga

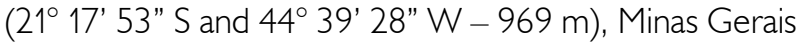
state. We used sherman traps $(250 \times 80 \times 90 \mathrm{~mm})$ arranged in linear transects with baits composed of a mixture of peanut butter, cod liver oil, sardines, cornmeal, banana

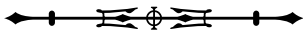




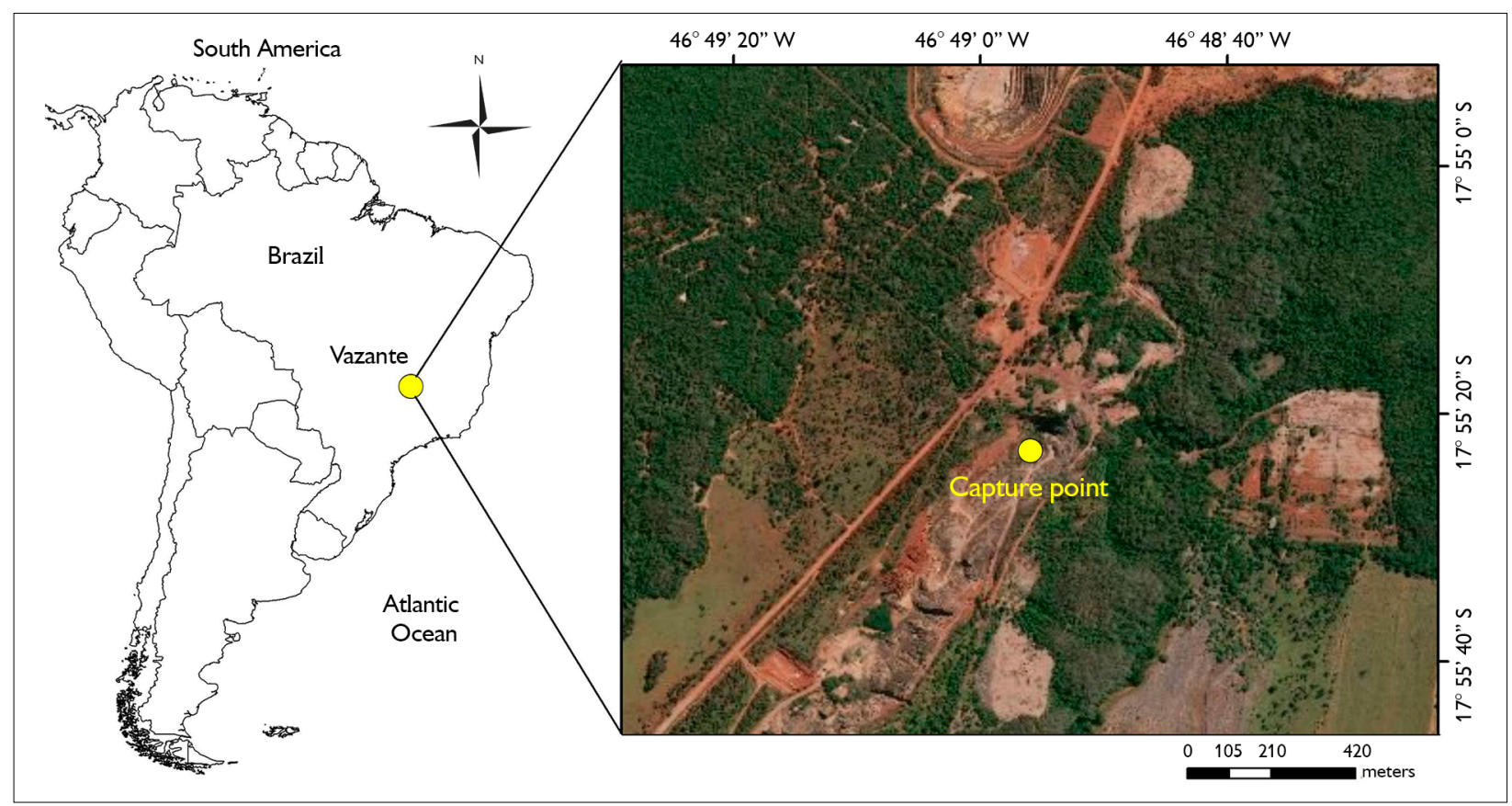

Figure 1. Study area map in Vazante municipality, Minas Gerais state, Southeastern Brazil. Map produced by the authors, 2020.

essence and mashed pineapple on small pieces of banana to capture both individuals (test and control). The species were identified following Gardner (2008).

The test animal came from a wildlife monitoring study and was captured in a forest area adjacent to a mining plant. We found the individual dead inside one of the Sherman traps after nine months of performing a capture-recapture program. The individual was taxidermized and its soft tissues and bones were divided into sub-samples (Table 1).

After obtaining the wet weight, the control and experimental samples were oven dried at $60^{\circ} \mathrm{C}$ for $12 \mathrm{~h}$, and then weighed again to perform the heavy metal analysis, in which each sub-sample had a minimum weight of $0.05 \mathrm{~g}$. This material was placed in Teflon ${ }^{\circledR}$ PTFE tubes with five milliliters of $\mathrm{HNO}_{3}$ (nitric acid) and microwaved at a pressure of $0.76 \mathrm{MPa}$ and a temperature of $175^{\circ} \mathrm{C}$ for $10 \mathrm{~min}$. $\mathrm{Cd}$ and $\mathrm{Pb}$ contents were determined by atomic absorption spectrophotometry using a PerkimElmerAAnalyst $800^{\circledR}$ flame atomizer (similar to Carvalho et al., 2013).
Table 1. Sub-samples obtained from the animal test and respective references for the quantitative analysis of cadmium and lead.

\begin{tabular}{c|c}
\hline Sub-samples & References \\
\hline 1 & Liver, heart, spleen and kidneys \\
\hline 2 & Intestine and stomach \\
\hline 3 & Thoracic and pelvic limbs \\
\hline 4 & Ribs \\
\hline 5 & Vertebra \\
\hline
\end{tabular}

\section{RESULTS \& DISCUSSION}

The results showed that the specimen captured near the mining area had high levels of cadmium and lead when compared to the control samples. These values showed differences between some of the sub-samples (1 to 5 Figures 2 and 3). The cadmium and lead contents present in the test animal are highly discrepant in relation to those found in the control samples.

The results demonstrated the potential of small terrestrial mammals as a bioindicator, in this case using the Brazilian gracile opossum of the Gracilinanus microtarsus

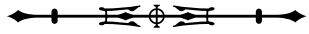


species. Lead accumulation in trialkylated form (Leite, 2006) can affect organs in the different body systems such as endocrinology and cardiovascular, among others. Furthermore, this heavy metal can also accumulate in bone tissues (Moreira, F. \& Moreira, J., 2004). In the case of Cadmium, interaction with the liver results in oxidative stress, competing with zinc for protein binding sites and causing DNA strand breaks, or inhibiting the pathway associated with repair of base-pairing DNA (Lauer, 2007). Moreover, Cadmium negatively affects reproduction, and causes cardiotoxicity, hepatotoxicity, and neurotoxicity (Tomza-Marciniak et al., 2019). Critical levels reported in the literature are $15 \mu \mathrm{g} / \mathrm{g}$ of lead in mammals in general (Ma, 2011) and 30-60 mg/kg of wet weight and $105-210 \mathrm{mg} / \mathrm{kg}$ of dry weight of small mammals for cadmium (Cooke, 2011). It is reiterated that these values were analyzed in large animals, such as cattle, monkeys, dogs and rats in Ma (2011) and the values to Cooke (2011) were found with captive wild European species studied in the laboratory with chronic oral doses equivalent to those encountered by wild small mammals in contaminated habitats. Therefore, the levels found in our research are considered high in relation to these critical levels.

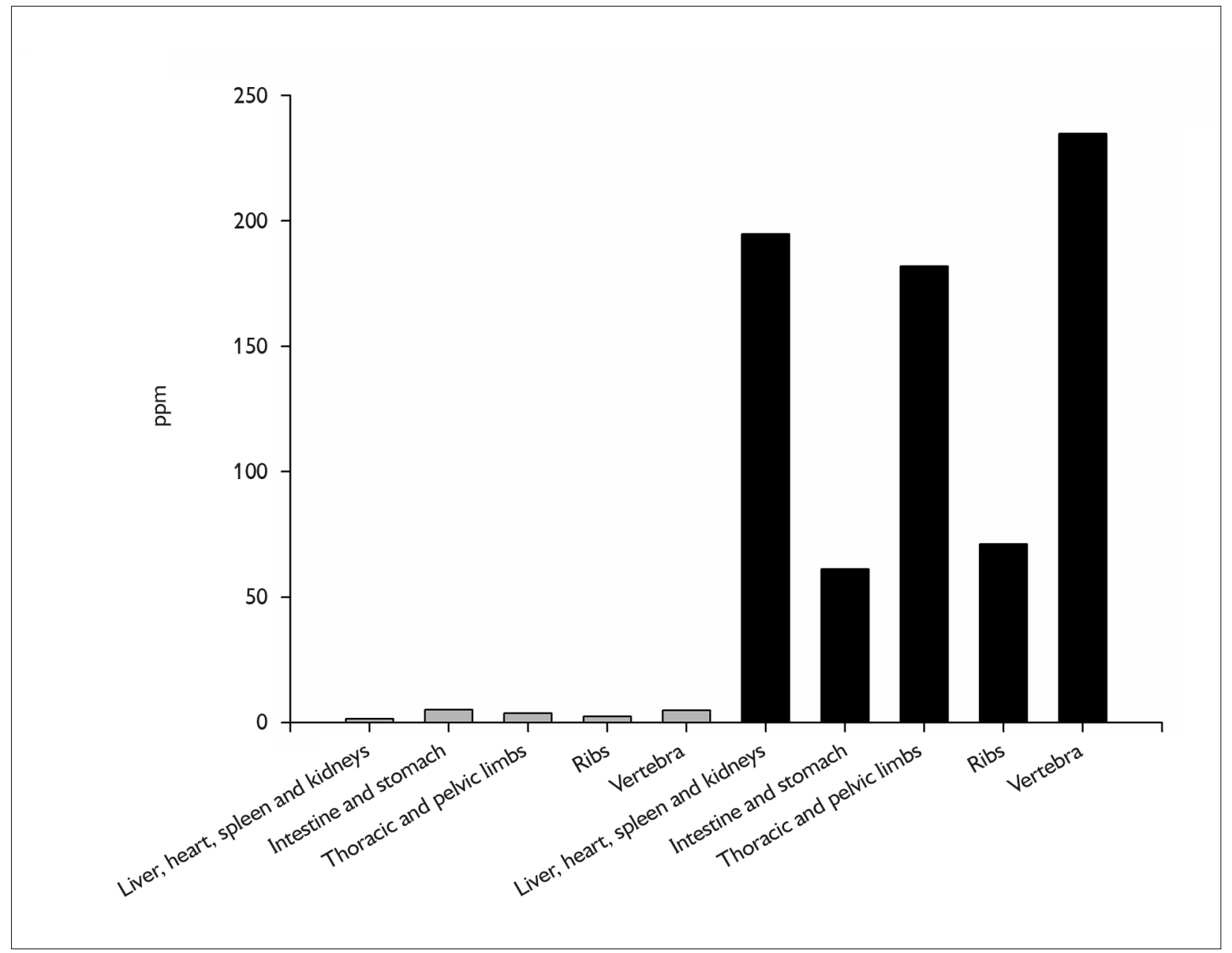

Figure 2. Cadmium contents accumulated in tissues of small terrestrial mammals in ppm. The gray bars represent the sub-samples from the control animal, and black bars represent the sub-samples from the animal test.

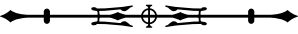




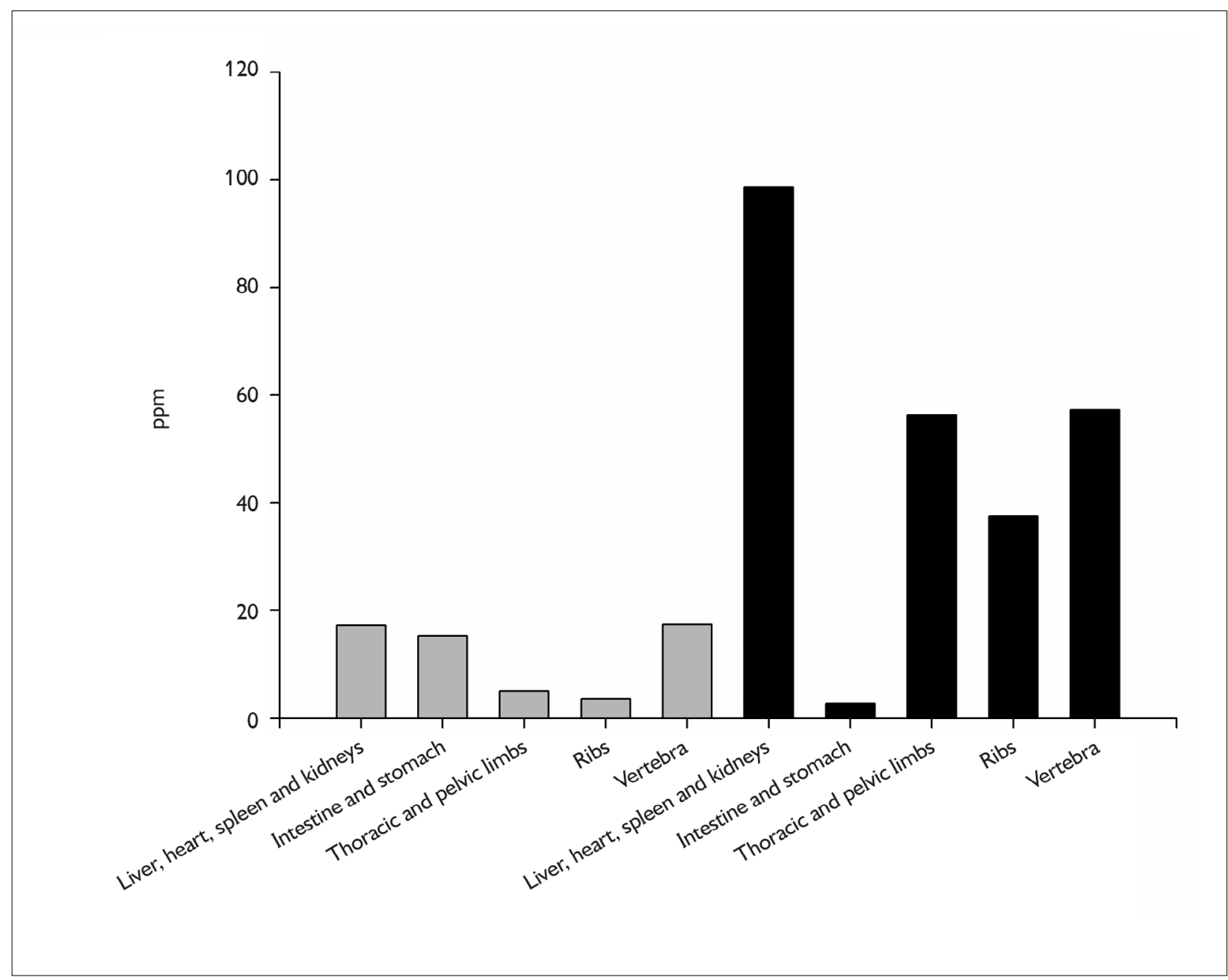

Figure 3. Lead contents accumulated in tissues of small terrestrial mammals in ppm. The numbers gray bars represent the sub-samples from the control animal, and black bars represent the sub-samples from the animal test.

These marsupials can bioaccumulate these two metals and disperse them in nature in different environments and in food chains. This can occur by the animal decomposing after death and/or when the animal is preyed upon by predators. Cadmium and lead are macronutrients. Only a few super-accumulating species can easily remove this metal from the soil [e.g., the plant species Gomphrena claussenii Moq. - Carvalho et al. (2013)]. Nevertheless, some animals can retain these elements, but carnivorous and omnivorous animals accumulate more than herbivores when feeding on smaller animals such as earthworms or other soil associated invertebrates (Ma, 1989; Veltman et al., 2007).

Some studies on bioaccumulation in Europe and Asia (e.g., Hamers et al., 2006; Veltman et al., 2007; Wijnhoven et al., 2007) found high cadmium values in the liver and kidney of herbivorous and carnivorous voles and shrews, correlating them with available soil elements. When studying sympatric species of small mammals in the north of France, Fritsch et al. (2010) verified different bioavailability response patterns, with age being a key factor in response to exposure to metals. 
In addition, this is the first report of bioaccumulation of these two chemical elements in neotropical marsupials and has the secondary objective of presenting technicalscientific arguments to encourage more studies in this line in South America, mainly in Brazil (Zocche et al., 2010). Ferreira et al. (2014) mentioned that Brazil has many mining (or degraded) zones, presenting ecological implications of the expansion of these areas. However, studies in Brazil focusing on mining impacts related on fauna contamination are still incipient.

Bioaccumulation in mammals of medium and large size has already been shown, mainly for capybara and marine mammals (e.g., Monteiro-Neto et al., 2003; Ramm, 2015), both related to the bioaccumulation of metals such as silver, lead, copper, zinc and cadmium due to agricultural activities (agrochemicals) which are leached into lakes and rivers. There are promising initiatives for small mammals in Brazil (e.g., Castro et al., 2018) with accumulation of Triphenyltin, and by Zocche et al. (2010) on the influence of heavy metals on blood cells in bats), however this study scope needs more attention by researchers, considering the increased contact with heavy metals and other toxic chemical elements from agrochemicals and mining activities in Brazil (for example, environmental disasters causing spillage of metal tailings in Mariana, in 2015, and Brumadinho, in 2019, in Minas Gerais state).

Our results raise questions about the bioaccumulation process from mining actvities: How much of the heavy metal bioaccumulation found in animals living in mining area surroundings is the result of the mining activities, and how much is result of an ecosystem established in an area which naturally has high concentrations of heavy metals? What is the concentration of heavy metals in surrounding soils and plants? What is the concentration of heavy metals in organisms consumed by the analyzed marsupial? Thus, these questions must be answered by future studies to clarify the environmental impacts of contaminating activities.

\section{ACKNOWLEDGMENTS}

We are grateful to the editor Alexandra Bezerra, Diogo Loretto and an anonymous reviewer for the considerations for improving previous version of this article. FSM received research fellowship from Fundação de Amparo à Pesquisa do Estado de Minas Gerais (FAPEMIG) (ID-11511); ASM received research fellowship from FAPEMIG (ID-11512); RFM research fellowship from Coordenação de Aperfeiçoamento de Pessoal de Nível Superior (CAPES) (Code 001).

\section{REFERENCES}

ANDREAZZI, C. S., A. S. PIRES \& A. S. FERNANDEZ, 2009. Mamíferos e palmeiras neotropicais: interações em paisagens fragmentadas. Oecologia Brasiliensis 13(4): 554-574. DOI: http:// doi.org/10.4257/oeco.2009.1304.02

ASTÚA, D., R. T. MOURA, C. E. GRELLE \& M. T. FONSECA, 2006. Influence of baits, trap type and position for small mammal capture in a Brazilian lowland Atlantic Forest. Boletim do Museu de Biologia Mello Leitão 19(1): 31-44.

BRIANI, D. C., A. R. PALMA, E. M. VIEIRA \& R. P. HENRIQUES, 2004. Post-fire succession of small mammals in the Cerrado of central Brazil. Biodiversity and Conservation 13(5): 1023-1037. DOI: https://doi.org/10.1023/B:BIOC.0000014467.27138.0b

CARVALHO, M. T. V., D. C. AMARAL, L. R. G. GUILHERME \& M. G. M. AARTS, 2013. Gomphrena claussenii, the first South-American metallophyte species with indicator-like $\mathrm{Zn}$ and $\mathrm{Cd}$ accumulation and extreme metal tolerance. Frontiers of Plant Science 4: 1-10. DOI: https://doi.org/10.3389/fpls.2013.00180

CASTRO, T. F., G. Q. SAALFELD, A. S. V. JUNIOR, F. F. PADILHA, K. S. SANTOS, D. M. PIRES, J. R. PEREIRA, C. D. CORCINI \& E. P. COLARES, 2018. Triphenyltin exposition induces spermatic parameter alters of Calomys laucha species. Chemosphere 211: 11761182. DOI: https://doi.org/10.1016/j.chemosphere.2018.08.048

CIONEK, V. M., G. H. Z. ALVES, R. M. TÓFOLI, J. L. RODRIGUESFILHO \& R. M. DIAS, 2019. Brazil in the mud again: lessons not learned from Mariana dam collapse. Biodiversity and Conservation 28(7): 1935-1938. DOI: https://doi.org/10.1007/s10531-019-01762-3

COOKE, J. A., 2011. Cadmium in small mammals. In: W. N. BEYER \& J. P. MEADOR (Ed.): Environmental contaminants in biota: interpreting tissue concentrations: 627-644. Taylor \& Francis Group, Boca Raton.

COSTA, E. P., Y. L. R. LEITE, S. L. MENDES \& A. D. DITCHFIELD, 2005. Mammal conservation in Brazil. Conservation Biology 19(3): 672-679. DOI: https://doi.org/10.1111/.1523-1739.2005.00666.x

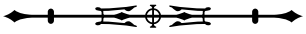


FAN, W., Z. XU \& W. WANG, 2014. Metal pollution in a contaminated bay: relationship between metal geochemical fractionation in sediments and accumulation in a polychaete. Environmental Pollution 191: 50-57. DOI: https://doi.org/10.1016/j. envpol.2014.04.014

FERREIRA, J., L. E. O. C. ARAGÃO, J. BARLOW, P. BARRETO, E. BERENGUER, M. BUSTAMANTE, T. A. GARDNER, A. C. LEES, A. LIMA, J. LOUZADA, R. PARDINI, L. PARRY, C. A. PERES, P. S. POMPEU, M. TABARELLI \& J. ZUANON, 2014. Brazil's environmental leadership at risk. Science 346(6210): 706-707. DOI: http://doi.org/10.1126/science.1260194

FINOTTI, R., M. M. SANTOS \& R. CERQUEIRA, 2012. Diet, digestive tract gross anatomy and morphometry of Akodon cursor Winge (Sigmodontinae): relations between nutritional content, diet composition and digestive organs. Mammalia 76(1): 81-89. DOI: https://doi.org/10.1515/mammalia-2012-0503

FISCHER, C., C. THIES \& T. TSCHARNTKE, 2011. Small mammals in agricultural landscapes: opposing responses to farming practices and landscape complexity. Biological Conservation 144(3): 11301136. DOI: https://doi.org/10.1016/j.biocon.2010.12.032

FRITSCH, C., R. P. COSSON, M. CEURDASSIER, F. RAOUL, P. GIRAUDOUX, N. CRINI, A. VAUFLEURYA \& R. SCHEIFLER, 2010. Responses of wild small mammals to a pollution gradient: host factors influence metal and metallothionein levels. Environmental Pollution 158(3): 827-840. DOI: https://doi.org/10.1016/j. envpol.2009.09.027

GARDNER, A. L., 2008. Mammals of South America: vol. 1: marsupials, xenarthrans, shrews, and bats. University of Chicago Press, Chicago.

GRAIPEL, M. E., J. J. CHEREM, P. R. M. MILLER \& L. GLOCK, 2003. Trapping small mammals in the forest understory: a comparison of three methods. Mammalia 67(4): 551-558. DOI: https://doi.org/10.1515/mamm-2003-0409

HAMERS, T., J. H. VAN DEN BERG, C. A. VAN GESTEL, F. J. VAN SCHOOTEN \& A. J. MURK, 2006. Risk assessment of metals and organic pollutants for herbivorous and carnivorous small mammal food chains in a polluted floodplain (Biesbosch, The Netherlands). Environmental Pollution 144(2): 581-595. DOI: https://doi. org/10.1016/j.envpol.2006.01.020

HICE, C. L. \& P. M. VELAZCO, 2013. Relative effectiveness of several bait and trap types for assessing terrestrial small mammal communities in Neotropical rainforest. Museum of Texas Tech University, Lubbock.

HORN, G. B., A. KINDLE \& S. M. HARTZ, 2008. Akodon montensis (Thomas, 1913) (Muridae) as a disperser of endozoochoric seeds in a coastal forest of southern Brazil. Mammalian Biology 73(4): 325-329. DOI: https://doi.org/10.1016/j.mambio.2007.10.008
HUNTER, B. A., M. S. JOHNSON \& D. J. THOMPSON, 1989. Ecotoxicology of copper and cadmium in a contaminated grassland ecosystem. IV. Tissue distribution and age accumulation in small mammals. Journal of Applied Ecology 26(1): 89-99. DOI: https:// doi.org/10.2307/2403653

KAUFMAN, D. W., G. A. KAUFMAN, P. A. FAY, J. L. ZIMMERMAN \& E. W. EVANS, 1998. Animal populations and communities. In: A. K. KNAPP, J. M. BRIGGS, D. C. HARTNETT \& S. L. COLLINS (Ed.): Grassland dynamics: 113-139. Oxford University Press, New York.

LAUER, C. M. J., 2007. A influência dos íons cálcio e magnésio na toxicidade do cádmio e o envolvimento da proteína Pmr1 no uso da via secretora para desintoxicação de cádmio em Saccharomyces cerevisiae. Masther Dissertation - Universidade Federal do Rio Grande do Sul, Porto Alegre.

LEITE, E. M. A., 2006. Exposição ocupacional ao chumbo e seus compostos. In: Apostila da Disciplina de Análises Toxicológicas: 1-23. Universidade Federal de Minas Gerais, Belo Horizonte.

MA, W.-C., T. EDELMAN, I. VAN BEERSUM \& T. JANS, 1983. Uptake of cadmium, zinc, lead, and copper by earthworms near a zincs melting complex: Influence of soil $\mathrm{pH}$ and organic matter. Bulletin of Environmental Contamination and Toxicology 30: 424-427.

MA, W.-C., 1989. Effect of soil pollution with metallic lead pellets on lead bioaccumulation and organ/body weight alterations in small mammals. Archives of Environmental Contamination and Toxicology 18: 617-622. DOI: https://doi.org/10.1007/BF01055030

MA, W.-C., 2011. Lead in mammals. In: W. N. BEYER \& J. P. MEADOR (Ed.): Environmental contaminants in biota: interpreting tissue concentrations: 595-608. Taylor \& Francis Group, Boca Raton.

MACHADO, F. S., R. GREGORIN \& P. S. B. MOUALLEM, 2013. Small mammals in high altitude phytophysiognomies in southeastern Brazil: are heterogeneous habitats more diverse? Biodiversity and Conservation 22(8): 1769-1782. DOI: https://doi.org/10.1007/ s10531-013-0511-7

MONTEIRO-NETO, C., R. V. ITAVO \& L. E. SOUZA MORAES, 2003. Concentrations of heavy metals in Sotalia fluviatilis (Cetacea: Delphinidae) of the coast of Ceará, northeast Brazil. Environmental Pollution 123(2): 319-324. DOI: https://doi.org/10.1016/S02697491(02)00371-8

MOREIRA, F. R. \& J. C. MOREIRA, 2004. Effects of lead exposure on the human body and health implications Rev. Revista Panamericana de Salud Publica 15(2): 119-129. DOI: https://doi.org/10.1590/ s1020-49892004000200007

MOREIRA, J. C., E. G. MANDUCA, P. R. GONÇALVES, M. M. MORAIS JR., R. F. PEREIRA, G. LESSA \& J. A. DERGAM, 2009. Small mammals from Serra do Brigadeiro State Park, Minas Gerais, southeastern Brazil: species composition and elevational distribution. Arquivos do Museu Nacional 67(1-2): 103-118.

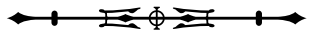


PAGLIA, A. P., G. A. B. FONSECA, A. B. RYLANDS, G. HERMANN, L. M. S. AGUIAR, A. G. CHIARELLO, Y. L. R. LEITE, L. P. COSTA, S. SICILIANO, M. C. M. KIERULFF, S. L. MENDES, V. C. TAVARES, R. A. MITTERMEIER \&J. L. PATTON, 2012. Annotated checklist of Brazilian mammals: 2. ed. Conservation International (Occasional Papers Conservation Biology), Arlington.

RAMM, C. B., 2015. Contaminação por metais nas capivaras Hydrochaeris hydrochaeris no Sul do Brasil. Masther Dissertation - Universidade Federal do Rio Grande, Rio Grande.

REDFORD, K. P. \& J. F. EISENBERG, 1992. Mammals of the Neotropics: the southern cone. University of Chicago, Chicago.

SANTORI, R. T., D. M. ASTÚA, D. GRELLE \& R. CERQUEIRA, 1997. Natural diet at a restinga forest and laboratory food preferences of the opossum Philander frenata in Brazil. Studies on Neotropical Fauna and Environment 32(1): 12-16. DOI: https://doi.org/10.1076/ snfe.32.1.12.13460

SANTORI, R. T., L. G. LESSA \& D. ASTÚA, 2012. Alimentação, nutrição e adaptações alimentares de marsupiais brasileiros. In: $\mathrm{N}$. C. CÁCERES (Ed.): Os marsupiais do Brasil: biologia, ecologia e evolução: 383-404. Editora da UFMS, Campo Grande.

THOMPSON, F., B. C. OLIVEIRA, M. C. CORDEIRO, B. P. MASI, T. P. RANGEL, P. PAZ, T. FREITAS, G. LOPES, B. S. SILVA, A. S. CABRAL, M. SOARES, D. LACERDA, C. S. VERGILIO, M. LOPES-FERREIRA, C. LIMA, C. THOMPSON \& C. E. REZENDE, 2020. Severe impacts of the Brumadinho dam failure (Minas Gerais, Brazil) on the water quality of the Paraopeba River. Science of the Total Environment 705: 135914. DOI: https://doi.org/10.1016/j. scitotenv.2019.135914
TOMZA-MARCINIAK, A., B. PILARCZYK, A. MARCINIAK, J. UDAŁA, M. BAKOWSKA \& R. PILARCZYK, 2019. Cadmium, Cd. In: K. ELZBIETA (Ed.): Mammals and birds as bioindicators of trace element contaminations in terrestrial environments: 483532. Springer, Cham.

VELTMAN, K., M. A. HUIJBREGTS, T. HAMERS, S. WIJNHOVEN \& A. J. HENDRIKS, 2007. Cadmium accumulation in herbivorous and carnivorous small mammals: Meta-analysis of field data and validation of the bioaccumulation model optimal modeling for ecotoxicological applications. Environmental Toxicology and Chemistry 26(7): 1488-1496. DOI: https://doi.org/10.1897/06-518R.1

VOSOOGH, A., M. SAEEDI \& R. LAK, 2016. Heavy metals relationship with water and size-fractionated sediments in rivers using canonical correlation analysis (CCA) case study, rivers of south western Caspian Sea. Environmental Monitoring and Assessment 188(11): 603. DOI: https://doi.org/10.1007/s10661-016-5611-x

WIJNHOVEN, S., R. S. E. W. LEUVEN, G. VAN DER VELDE, G. JUNGHEIM, E. I. KOELEMIJ, F. T. DE VRIES, H. J. P. EIJSACKERS \& A. J. M. SMITS, 2007. Heavy-metal concentrations in small mammals from a diffusely polluted floodplain: importance of speciesand location-specific characteristics. Archives of Environmental Contamination and Toxicology 52(4): 603-613. DOI: https://doi. org/10.1007/s00244-006-0124-1

ZOCCHE, J. J., D. D. LEFFA, A. P. DAMIANI, F. CARVALHO, R. A. MENDONÇA, C. E. I. DOS SANTOS, L. A. BOUFLEUR, J. F. DIAS \& V. M. ANDRADE, 2010. Heavy metals and DNA damage in blood cells of insectivore bats in coal mining areas of Catarinense coal basin, Brazil. Environmental Research 110(7): 684-691. DOI: https://doi.org/10.1016/j.envres.2010.06.003

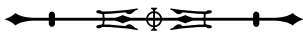

